\title{
Implementation of a patient and public involvement group in the context of palliative care research - Experiences from two projects on sedation in palliative care
}

\author{
Meesters S, Handtke V, Kühnel M B, Bausewein C, Schildmann E
}

Department of Palliative Medicine, University Hospital Munich, Ludwig-Maximilians-Universität (LMU) Munich, Germany

\section{Background}

Patient and Public Involvement (PPI) is an increasingly recognized approach to enhance research quality and relevance. It is defined as research being carried out "with" or "by" members of the public (Tab 1). Although $\mathrm{PPI}$ is now required by many research funding bodies, there are no resources to support its implementation in Germany to date.

\section{Tab. 1: Aims and Characteristics of PPI}

- Tims investigate topics important to the public
- To gain new and unique insights regarding project
- planning, conduct and evaluation
- po use appropriate and clear language for
- To report relevant outcomes in an accessible way
Characteristics
- Structured approach, researchers define tasks for
the PPI group (top-down approach)
- Limited to health research
- Professionals and political decision-makers are
explicitly not involved

\section{Aim}

To describe our first experiences regarding the implementation of a PPI group for two projects on sedation in palliative care.

\section{Results}

The present PPI group consists of 8 members (5 relatives of former palliative care patients, 1 patient, 1 former hospice volunteer, 1 student nurse). All were first contacted by a person known to them professionally. Subsequently, they received information via letter and phone call by our research team. All persons approached agreed to participate, except one. An introductory session was organized to get familiar and to present and discuss research basics, information about PPI, palliative care, the two research projects and potential tasks. Involvement during the earlier research stages was not possible, as the PPI group started at the same time as the projects. PPI so far comprised participation in the development of participant information leaflets and interview guides, attending project meetings and assisting in pilot interviews (Fig.2). Existing international resources (e.g. "INVOLVE") could only partly be applied due to different structural conditions.

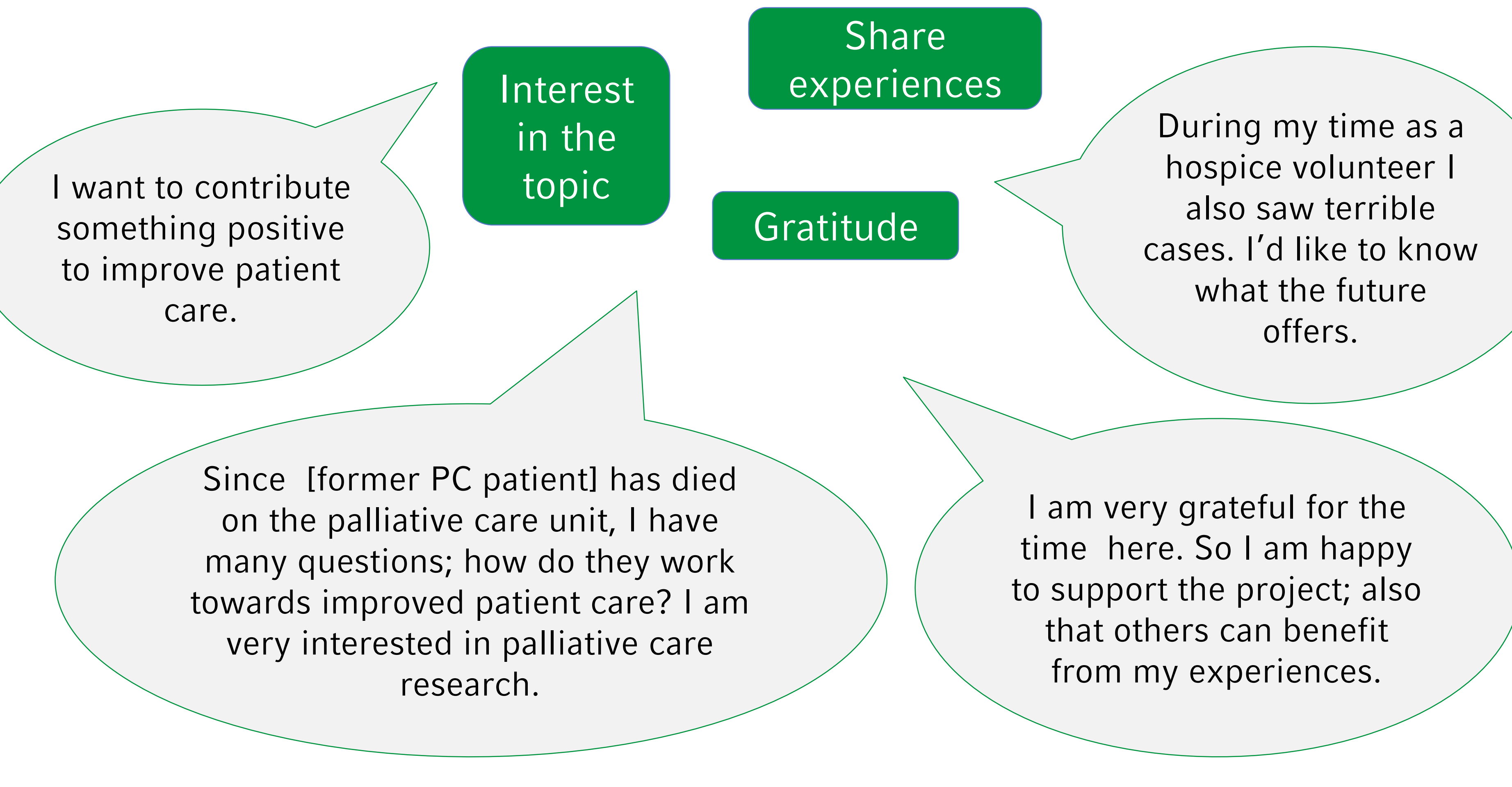

Fig.1: Motivation for participating in the PPI group

\begin{tabular}{|c|c|c|c|}
\hline $\begin{array}{c}\text { * } \text { Research } \\
\text { Question } \\
\text { Specification }\end{array}$ & $\begin{array}{l}\text { * Research } \\
\text { Planning }\end{array}$ & $\begin{array}{l}\text { Research } \\
\text { Conduct }\end{array}$ & $\begin{array}{c}\text { Outcome } \\
\text { Dissemination }\end{array}$ \\
\hline $\begin{array}{l}\text { - } \text { Pointing out } \\
\text { research } \\
\text { gaps } \\
\text { - Determining } \\
\text { patient } \\
\text { relevant } \\
\text { results and } \\
\text { added value }\end{array}$ & $\begin{array}{l}\text { - Evaluating the } \\
\text { benefit - effort - } \\
\text { balance } \\
\text { - Determining the } \\
\text { target population } \\
\text { - Evaluating } \\
\text { ethical concerns } \\
\text { and data } \\
\text { protection } \\
\text { - Evaluating the } \\
\text { user-friendliness }\end{array}$ & $\begin{array}{l}\text { - Evaluating } \\
\text { participant material } \\
\text { - Attending project } \\
\text { meetings } \\
\text { - Discussing first } \\
\text { results } \\
\text { - Monitoring the } \\
\text { compliance with } \\
\text { data protection } \\
\text { and participant } \\
\text { safety } \\
\text { - Supporting the } \\
\text { recruitment of } \\
\text { participants }\end{array}$ & $\begin{array}{l}\text { - Discussing } \\
\text { results } \\
\text { - Supporting } \\
\text { user-friendly } \\
\text { dissemina- } \\
\text { tion of } \\
\text { relevant } \\
\text { outcomes }\end{array}$ \\
\hline
\end{tabular}

* possible but not realised tasks

Fig. 2: Potential tasks for PPI

(summarised and adapted from INVOLVE and EUPATI)

\section{Conclusion}

PPI recruitment proved successful, and first involvement helped to improve the research process. However, creating effective and sustainable $\mathrm{PPI}$ requires resources and guidance as well as exchange between research groups. Particularly to ensure involvement in the early project stages (before application), a national programme bringing together expertise and experience and providing training and resources regarding $\mathrm{PPI}$, such as "INVOLVE" in the UK, would be desirable. 